Capitalism Contested 



\title{
Capitalism Contested
}

The New Deal and Its Legacies

\author{
Edited by \\ Romain Huret, \\ Nelson Lichtenstein, \\ and \\ Jean-Christian Vinel
}

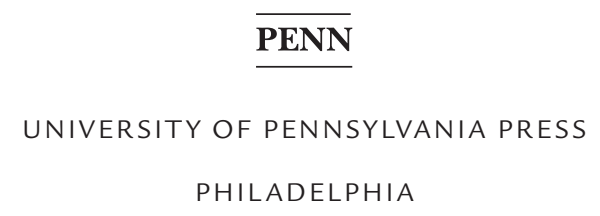


Copyright $\odot 2020$ University of Pennsylvania Press

All rights reserved. Except for brief quotations used for purposes of review or scholarly citation, none of this book may be reproduced in any form by any means without written permission from the publisher.

Published by

University of Pennsylvania Press

Philadelphia, Pennsylvania 19104-4112

www.upenn.edu/pennpress

Printed in the United States of America on acid-free paper

109887665443221

Library of Congress Cataloging-in-Publication Data

Names: Huret, Romain, editor. | Lichtenstein, Nelson, editor. |

Vinel, Jean-Christian, editor.

Title: Capitalism contested : the New Deal and its legacies / edited by Romain Huret, Nelson Lichtenstein, and Jean-Christian Vinel.

Description: Philadelphia : University of Pennsylvania Press, [2020] |

Includes bibliographical references and index.

Identifiers: LCCN 2020010042 | ISBN 978-0-8122-5262-0 (hardcover)

Subjects: LCSH: New Deal, 1933-1939. | Capitalism-United States-

History-20th century. | Capitalism-United States-History-

21st century. | United States-Economic policy-20th century. |

United States-Economic policy-21st century. | United States-

Economic conditions-20th century. | United States-Economic

conditions-21st century. | United States-Politics and

government-20th century. | United States-Politics and government-

21 st century.

Classification: LCC E806 .C325 2020 | DDC 973.917—dc23

LC record available at https://lccn.loc.gov/2020010042 